\title{
Urgensi Perubahan Paradigma Hukum dalam Pengelolaan Sumber Daya Air Nasional
}

Jundiani

Staf Pengajar Fakultas Syariah UIN Malang .

\section{Abstract}

This paper discusses operational and legal paradigm aspects of water resources management in Indonesia. Principles and concepts of anthropocentrism and holism are presented. Issues discussed are legal idiology and legal paradigm of national water resources mangement. The paper concludes with an outlook on the needs for development of legal paradigm and community-based water resources managemem.

\section{Pendahuluan}

Air adalah senyawa yang dibutuhkan dalam kehidupan manusia. Adanya keyakinan bahwa air merupakan berkah dan sumber kehidupan sehingga mewujudkan nilai universal yang terus hidup dalam tradisi, kepercayaan, dan bahkan agama yang dianut oleh masyarakat di dunia. Agama-agama yang ada di dunia, apakah Budha, Yahudi, Hindu, Kristen dan juga Islam, kisah-kisah dan ayat-ayat yang berkaitan dengan fungsi air sangat banyak jumlahnya. Sebagai pemeluk Islam, dapat dikaji dalam Al-Qur'an yaitu dalam surat Al-Baqarah:164, Al-Hajj:5, ${ }^{2}$ Al-Furqaan:48, ${ }^{3}$ dan surat Al-Qaaf:9. ${ }^{4}$ Kitab suci Al-Quran menjelaskan, 
kata 'air' disebutkan lebih dari enam puluh kali, 'sungai' lebih dari lima puluh kali, dan 'laut' lebih dari empat puluh kali. ${ }^{5}$

Air merupakan bagian terbesar dari sumber daya alam yang mutlak diperlukan bagi hidup dan kehidupan, tidak hanya manusia tetapi juga makhluk hidup lain beserta lingkungannya. Sistem tata lingkungan meletakkan air pada suatu bagian utama dalam kehidupan sehingga kebutuhan manusia terhadap air selalu meningkat dari waktu ke waktu, bukan saja karena meningkatnya jumlah manusia yang memerlukan air tersebut, melainkan juga karena meningkatnya intensitas dan ragam kebutuhan akan air.

Air yang tersedia di Bumi Nusantara secara potensial yang dimanfaatkan oleh penduduknya yang dalam kajian siklus hidrologi, adalah tetap saja jumlahnya. Sebagai bagian terbesar dari sumber daya alam yang ada, ketersediaan air bagi kebutuhan manusia baik jumlah maupun kualitasnya bervariasi menurut ruang dan waktu. Namun persediaan air beserta sumber-sumbernya yang melimpah ini karena ditunjang oleh kondisi curah hujan yang tinggi dan beriklim basah, kenyataannya justru sebaliknya, menunjukkan bahwa persediaan air menjadi semakin langka, terutama bila dipandang dari waktu, tempat, dan kualitasnya. Hal demikian ini ditegaskan pula oleh Soenarno, bahwa kebutuhan air untuk sektor pertanian di Indonesia diperkirakan masih sekitar $80 \%$ dari total kebutuhan air. Dengan semakin bertambahnya penduduk dan berkembangnya pembangunan sektor lain, maka dikhawatirkan eksistensi jaminan alokasi air untuk sektor pertanian akan menjadi labil dan tergeser oleh kebutuhan air untuk sektor lainnya. ${ }^{6}$

Kondisi krisis air ini diperburuk dengan adanya penebangan hutan yang tidak terkontrol di daerah hulu sungai, eksploitasi air dan sumber-sumbernya yang semakin meningkat di berbagai wilayah dan pengalihan penggunaan daerah tangkapan air secara besar-besaran dan tidak terkontrol mengakibatkan keseimbangan ekologis-hidrologis terganggu sehingga akhimya mengurangi ketersediaan air pada musim kemarau.

Sehubungan dengan peningkatan kepadatan baik pembangunan industri maupun populasi manusia maka ketersediaan dan kebutuhan air pada musim kemarau menjadi hal yang sangat penting dalam menentukan kebijakan pengelolaan dan alokasi air di Indonesia. Adapun ketersediaan dan kebutuhan air pada musim kemarau tahun 2003 sebagai berikut : 


\section{Neraca Air Tahun 2003}

\begin{tabular}{|l|c|c|c|c|c|}
\hline \multirow{3}{*}{ PULAU } & \multicolumn{4}{|c|}{ TAHUN 2003 } & \multirow{2}{*}{ NERACA } \\
\cline { 2 - 5 } & \multicolumn{4}{|c|}{ Kebutuhan (Kemarau) } & \multicolumn{2}{|c|}{$\begin{array}{c}\text { Ketersediaan } \\
\text { (Kemarau) }\end{array}$} & \\
\cline { 2 - 5 } & Miliar m3 & $(\%)^{*}$ & Miliar m3 & $(\%)^{*}$ & \\
\hline Sumatera & 11,6 & 17,5 & 96,2 & 19,9 & Surplus \\
Jawa-Bali & 38,4 & 57,8 & 25,3 & 5,2 & Defisit \\
Kalimantan & 2,9 & 4,3 & 167,0 & 34,6 & Surplus \\
Nusa Tenggara & 4,3 & 6,5 & 4,2 & 0,9 & Defisit \\
Sulawesi & 9,0 & 23,6 & 14,4 & 3,0 & Surplus \\
Maluku & 0,1 & 0,2 & 12,4 & 2,6 & Surplus \\
Papua & 0,1 & 0,1 & 163,6 & 33,9 & Surplus \\
\hline
\end{tabular}

Keterangan: * $=$ Persentase terhadap total nasional

Sumber: Direktorat Jendral Sumber Daya Air Depkimpraswi]

Perkembangan jumlah penduduk yang demikian pesatnya seiring dengan pembangunan akan pemenuhan fasilitas pelayanannya di berbagai sektor, maka sebagian besar daerah tangkapan air berubah fungsi menjadi kawasan pemukiman. pertanian, maupun perindustrian yang mengakibatkan terjadinya krisis air yang mengancam pada setiap musim kemarau. Hal demikian ini menyebabkan pula banjir dan erosi pada setiap musim hujan.

Pembangunan kegiatan perekonomian di negara-negara yang baru merdeka dalam perspektif strategi pembangunan nasional sering menggunakan paradigma pertumbuhan ekonomi. Hal ini merupakan kebutuhan bagi negara yang baru merdeka untuk meningkatkan pendapatan bagi kesejahteraan rakyatnya. Pembangunan nasional dalam pengelolaan sumber daya alam dan lingkungan, termasuk pengelolaan sumber daya airnya, masih dipandang dalam konteks economic sense belaka dan belum dipahami sebagai ecological and sustainable sense. Dari perspektif strategi pembangunan nasional di negara-negara yang baru merdeka tersebut maka berbagai ragam kebijakan yang dijalankan termasuk dalam pengelolaan sumber daya airnya, sebagaimana yang terjadi selama ini di 
Indonesia, adalah berorientasi pada pemenuhan pertumbuhan ekonomi. Dengan demikian permasalahan yang diangkat dalam kajian ini adalah bagaimana urgensi perubahan paradigma hukum dalam pengelolaan sumber daya air nasional.

\section{Pembahasan}

\subsection{Ideologi Hukum Pengelolaan Sumber Daya Air Nasional}

Keberadaan hukum pengelolaan sumber daya air selama ini tidak terlepas dari ideologi hak menguasai negara yang dianut oleh Pasal 33 ayat (3) UndangUndang Dasar 1945 yang mengatur bahwa: "Bumi dan air dan kekayaan alam yang terkandung di dalamnya dikuasai oleh negara dan dipergunakan untuk sebesar-besar kemakmuran rakyat." Ketentuan Pasal 33 ayat (3) Undang-Undang Dasar 1945 ini dituangkan lagi dalam rumusan Pasal 2 Undang-Undang Nomor 5 Tahun 1960 tentang Peraturan Dasar Pokok-pokok Agraria, ${ }^{7}$ yang mengatur bahwa:

(1) Atas dasar ketentuan dalam Pasal 33 ayat 3 Undang-Undang Dasar dan halhal sebagai yang dimaksud dalam pasal 1: bumi, air dan ruang angkasa, termasuk kekayaan alam yang terkandung di dalamnya itu pada tingkatan tertinggi dikuasai oleh Negara, sebagai organisasi kekuasaan seluruh rakyat;

(2) Hak menguasai dari Negara termasuk dalam ayat 1 pasal ini memberi wewenang untuk:

a. Mengatur, dan menyelenggarakan peruntukan, penggunaan, persediaan dan pemeliharaan bumi, air dan ruang angkasa tersebut;

b. Menentukan dan mengatur hubungan-hubungan hukum antara orang-orang dengan bumi, air dan ruang angkasa;

c. Menentukan dan mengatur hubungan-hubungan hukum antara orang-orang dan perbuatan-perbuatan hukum yang mengenai bumi, air dan ruang angkasa;

(3) Wewenang yang bersumber pada hak menguasai dari Negara tersebut pada ayat 2 pasal ini digunakan untuk mencapai sebesar-besar kemakmuran rakyat, dalam arti kebangsaan, kesejahteraan dan kemerdekaan dalam masyarakat dan Negara hukum Indonesia yang merdeka, berdaulat, adil dan makmur; 
(4) Hak menguasai dari Negara tersebut di atas pelaksanaannya dapat dikuasakan kepada daerah-daerah Swatantra dan masyarakat-masyarakat hukum adat, sekedar diperlukan dan tidak bertentangan dengan kepentingan nasional, menurut ketentuan-ketentuan Peraturan Pemerintah.

Para pendiri Republik Indonesia (the founding fathers) nampakny a belum pernah memperkirakan, bahwa ideologi hak menguasai negara tersebut akan dimanfaatkan oleh Pemerintah yang berkuasa untuk memperkuat serta mempertahankan kekuasaannya dengan melaksanakan pembangunan nasional yang berorientasi pada pertumbuhan ekonomi belaka, sehingga melakukan strategi pembangunan hukum yang represif (repressive law) dan bersifat positivis instrumentalis. Hal demikian ini tidak sejalan dengan tujuan ideologi tersebut sebagaimana yang dinyatakan A.P. Parlindungan bahwa hak menguasai negara ini bertujuan untuk menjaga keseimbangan dan mengayomi masyarakat dari kekuatan-kekuatan yang mengancam rakyat kecil atau petani lemah. ${ }^{8}$

Perwujudan dari model hukum yang bersifat represif (repressive law), menurut I Nyoman Nurjaya adalah hukum yang bercirikan dengan pendekatan sekuriti (security approach), menekankan sanksi dan mengedepankan eksistensi para aparat pemerintah. ${ }^{9}$ Sehingga konsekuensi yuridis yang muncul adalah setiap penduduk yang mengakses serta memanfaatkan air beserta sumber-sumbernya yang telah dilakukannya sejak dulu dan belum memenuhi formalitas yang telah ditentukan oleh pemerintah maka dapat dikualifikasi atau distigmatisasi sebagai pelanggar hukum.

Dalam tatanan hukum represif, hukum sebagai alat dalam menjalankan kekuasaan represif dari pemerintah yang berdaulat, sehingga mampu mengemban kekuasaan politik dan kewenangan yang berasal dari negara melalui peraturan perundang-undangan. Dalam tipe hukum represif ini, maka hukum dan negara serta hukum dan politik tidak terpisah, sehingga aspek instrumental dari hukum sangat menonjol daripada aspek ekspresifnya. ${ }^{10}$

Kedudukan Negara yang dominan telah menerima hak menguasai kemudian memberikan kewenangan dalam pengelolaan air dan sumber-sumbernya kepada Pemerintah. Namun dalam konteks ini negara yang seringkali dipersonifikasikan sebagai pemerintah menjadi penafsir tunggal terhadap perencanaan, pengaturan dan pelaksanaan, pengawasan serta evaluasi kebijak an hukum pengelolaan sumber daya air. Hal ini sangat bertentangan dengan substansi dalam sebuah negara 
yang berdasarkan kedaulatan rakyat yang seharusnya rakyatlah yang menjadi unsur utama dalam sebuah negara tersebut.

Konsekuensi yuridis dengan dilaksanakannya government-based resources control and management dalam pengelolaan sumber daya air selama ini adalah posisi rakyat menjadi tidak sejajar dengan pemerintah sebagai penerima wewenang dari negara dalam kehidupan berbangsa dan bernegara. Paradigma ini memberi otoritas dan legitimasi yang penuh kepada negara untuk mengklaim, menguasai, mengatur, mengelola dan mengusahakan sesuai dengan kepentingan negara. Hal ini berarti telah terjadi pembentukan hubungan yang bersifat subordinasi antara rakyat dengan pemerintah, atau dengan kata lain bahwa rakyat dalam posisi yang inferior dan pemerintah dalam kedudukan yang superior. ${ }^{13}$

Hubungan yang bersifat sub-ordinasi ini juga telah mengakibatkan terjadinya keguncangan sosial di tingkat rakyat, yakni hilangnya akses dan kontrol rakyat terhadap pengelolaan sumber daya aimya. Kondisi inilah yang banyak digugat, baik oleh aktivis Lembaga Swadaya Masyarakat (LSM), golongan akademisj serta rakyat sendiri. Konflik-konflik dalam memenuhi kebutuhan air di tingkat rakyat seringkali diselesaikan secara represif yang kuantitasnya semakin lama semakin sering terjadi, tanpa adanya suatu penyelesaian yang bijaksana. Sebagaimana contoh tentang konflik air di Lampung, yaitu sekitar 612 nelayan tradisional dan 72 petani ikan nila yang berada di sungai Way Seputih dan Way Terusan menuntut keadilan, diakibatkan pencemaran air sungai yang dilakukan oleh 2 industri pabrik sehingga mengakibatkan matinya 900 ton ikan nila atau kerugian petani mencapai Rp. 4,5 milyar. ${ }^{12}$ Contoh tersebut hanya sebagian kecil dari terjadinya konflik air antara masyarakat lokal dengan pengguna air pada sektor lainnya. Ironisnya, dari konflik air tersebut masyarakat lokal tidak berdaya menghadapinya, oleh karena rakyat tidak mempunyai ijin dalam pemanfaatan air karena belum menjalani prosedur/formalitas yang telah ditentukan. Sedangkan penggunaan air pada sektor modern (non-pertanian) selalu mempunyai surat ijin penggunaan air, sehingga pada saat terjadi konflik air, masyarakat lokal senantiasa pada posisi yang lemah. 


\subsection{Paradigma Hukum Pengelolaan Sumber Daya Air Nasional}

Sebagaimana telah diketahui bahwa dasar penguasaan pengelolaan sumber daya air di Indonesia tertuang di dalam pasal 33 ayat (3) Undang-Undang Dasar 1945 yang mengatur bahwa: "Bumi dan air dan kekayaan alam yang terkandung di dalamnya dikuasai oleh negara dan dipergunakan untuk sebesar-besar kemakmuran rakyat". Konsep dasar penguasaan dan pengelolaan atas kekayaan alam dan isinya ini dikembangkan dari konsep negara kesejahteraan (welfare state concept).

Dalam negara kesejahteraan, negara dianggap sebagai mesin raksasa (giant machine) untuk membuat dan menerapkan hukum. Negara berfungsi sebagai pengendali sosial, namun pengendalian atau kontrol yang dilakukan tersebut melalui hukum. Konsep ini menunjukkan perbedaan antara Negara dengan Pemerintah sangat tipis, sebagaimana dinyatakan oleh Lawrence M. Friedman bahwa:". . welfare state, or, more broadly, the welfare-regulatory state. Basically, it is an active, interventionist state. Government is ubiquitous". ${ }^{3}$ Kekuasaan Pemerintah berada dalam segala kehidupan masyarakat, sehingga pemerintah dianggap merupakan jawaban atas segala permasalahan yang ada dalam kehidupan rakyat. Tindakan Pemerintah dalam negara kesejahteraan merupakan sebuah tindakan intervensi terhadap kehidupan rakyat.

Paradigma dalam kehidupan bermasyarakat, berbangsa dan bernegara dalam bentuk negara kesejahteraan ini sebagaimana yang terjadi dalam penyelenggaraan negara di Indonesia adalah paradigma negara, ${ }^{14}$ karena sulit dibedakan antara pemerintah sebagai salah satu unsur negara dengan negara itu sendiri, maka pemerintah akan menampakkan diri sebagai negara. Sebagaimana yang dinyatakan oleh Lawrence M. Friedman bahwa: “. . The welfare and regulatory state is a state committed to programs. Government is a problemsolver, as well as the guardian of law". ${ }^{15}$ Pemerintah adalah problem solver dan pelaksana kedaulatan hukum, sehingga tindakan melawan pemerintah akan diartikan sebagai tindakan melawan negara.

Ideologi hukum Hak Menguasai Negara yang terkandung dalam Pasal 33 ayat (3) Undang-Undang Dasar 1945 dan dalam Pasal 2 ayat (1) UndangUndang Nomor 5 Tahun 1960 tentang Ketentuan Dasar Pokok-pokok Agraria dengan jelas menyatakan bahwa atas dasar ketentuan dalam Pasal 33 ayat (3) 
Undang-Undang Dasar 1945 dan hal-hal sebagai yang dimaksud dalam pasal 1." Bumi, air, dan ruang angkasa termasuk kekayaan alam yang terkandung dj dalamnya itu pada tingkatan tertinggi dikuasai oleh negara sebagaj organisasi kekuasaan seluruh rakyat. ${ }^{16}$

Ideologi hukum Hak Menguasai Negara dalam pelaksanaannya telah mengaburkan hak-hak rakyat atas pengelolaan dan alokasi air beserta sumbersumbernya karena Pemerintah Indonesia menggunakan paradigma negara kekuasaaan ${ }^{17}$ sebagai dasar pendekatan untuk menjalankan kekuasaannya, sehingga hukum hanya sebagai pengabdi kekuasaan. Kondisi demikian ini dapat terjadi, karena Pemerintah menampakkan diri atau menjelma menjadi negara sebagaimana yang terjadi selama ini, yakni Pemerintah Indonesia melaksanakan fungsi pembangunan ekonomi nasional yang berorientasi pada pertumbuhan belaka dengan melalui paradigma negara kekuasaan.

Program pembangunan nasional yang dilaksanakan oleh pemerintah di dasarkan atas paradigma pembangunan ekonomi, yakni pertumbuhan ekonomi (economical growth) belaka. Dengan demikian segenap komponen bangsa, termasuk didalamnya adalah hukum sumber-sumber daya alam dan lingkungan dieksploitasi untuk mendorong terciptanya pertumbuhan ekonomi, sehingga pencapaian pertumbuhan ekonomi belaka melalui paradigma kekuasaan akan memarginalkan hukum yang berakibat pengabaian hak-hak rakyat atas sumber daya air dan lingkungan maupun pelestariannya. ${ }^{18}$

Pemerintah Indonesia melaksanakan fungsi pembangunan didalam pembangunan nasional dengan alasan demi kepentingan negara dan kepentingan rakyat. Alasan demikian ini pula sebagai justifikasi sentralisasi pengelolaan air beserta sumber-sumbernya yang dilakukan oleh Pemerintah. Dalam sejarah pemerintahan Indonesia, dengan alasan tersebut maka diterapkan paradigma hukum sentralistik ${ }^{19}$ dalam pengelolaan dan alokasi air beserta sumbersumbernya di Indonesia.

Berdasarkan kepentingan negara dan kepentingan rakyat sebagaimana yang dikemukakan oleh Pemerintah, mengakibatkan kondisi contradictio in terminis dalam pelaksanaannya. Dalam hal ini telah menimbulkan pertentangan kepentingan sehingga mengaburkan atau berkurangnya pengakuan hak-hak rakyat di dalam pengelolaan air beserta sumber-sumbernya yang pada kenyataannya telah dilakukan masyarakat sejak negara ini belum ada. 
Pemerintah sebagai elit kekuasaan yang bekerja untuk mencapai tujuan dalam mewujudkan kesejahteraan rakyat, juga telah menggunakan paradigma hukum sentralistik yang mempunyai kecenderungan menjalin hubungan simbiosis mutualisma dengan kelompok masyarakat tertentu dalam pengelolaan dalam pemanfaatan air dan sumber-sumbernya, sehingga hak-hak tersebut hanya dinikmati oleh kelompok tertentu pula. ${ }^{20}$

\subsection{Perubahan Paradigma Hukum dalam Pengelolaan Sumber Daya Air Nasional}

Frederiksen dari World Bank, Washington D.C. menyatakan: "The role of government and even the form of government are being greatly altered in several countries, while the approach to resource management is undergoing technological and philosophical changes." "2Telah diketahui bahwa bentuk peran pemerintah di beberapa negara telah mengalami perubahan besar, sejalan dengan perubahan filosofis maupun teknologis dalam pendekatan pengelolaan sumber daya alam.

Meskipun telah diadakan peningkatan kelembagaan dan peranannya, termasuk aturan-aturan maupun prosedur-prosedur yang telah diformalisasikan melalui usaha yang rasional dari para pihak yang berkepentingan untuk dapat mengkondisikan perubahan dalam pendekatan pengelolaan sumber daya alam, akan tetapi kenyataan ini tidak selalu menghasilkan tujuan yang sudah ditetapkan.

Kegagalan pendekatan rasional, positivistik dan antroposentrik dalam pengelolaan sumber daya alam, termasuk pengelolaan dalam pemanfaatan air dan sumber-sumbernya, karena dasar kebijakan lingkungan yang berorientasi antroposentris adalah senantiasa berubah sejalan dengan perubahan kebutuhan manusia.

Konsep anthropocentris yang memandang manusia itu berkuasa atas sumber daya alam dan lingkungan harus diubah menjadi konsep holism. yaitu sikap yang menempatkan 'kebersamaan' antara manusia dengan sumber daya alam dan lingkungan. Perubahan yang menuju pada sikap kebersamaan manusia dengan lingkungan ini sebagai ekspresi bahwa manusia harus menghargai sumber daya alam dan lingkungan karena sumber daya alam dan lingkungan memiliki 
keterbatasan. Kendatipun manusia mempunyai hak untuk mengelola lingkungan, akan tetapi juga mempunyai kewajiban untuk melestarikannya, sehingga tidak akan mengganggu kepentingan generasi sekarang maupun generasi mendatang.

Konsep holism ini sejalan dengan pengaturan pengelolaan lingkungan hidup yang tertuang dalam Undang-Undang Nomor 23 Tahun 1997 tentang Pengelolaan Lingkungan hidup..$^{22}$ Lebih jauh pengaturan prinsip berkelanjutan dan holisme tersebut dijabarkan dalam pasal 4 , yang mengatur sasaran pengelolaan lingkungan hidup, yakni: (a) tercapainya keselarasan, keserasian, dan keseimbangan antara manusia dan lingkungan hidup; (b) terwujudnya manusia Indonesia sebagai insan lingkungan hidup yang memiliki sikap dan tindak melindungi dan membina lingkungan hidup; (c) terjaminnya kepentingan generasi masa kini dan generasi masa depan; (d) tercapainya kelestarian fungsi lingkungan hidup; dan (e) terkendalinya pemanfaatan sumber daya secara bijaksana.

Mengkaji lebih jauh konsep tersebut di atas, maka pengelolaan sumber daya air nasional dalam prakteknya selama ini dilakukan melalui pendekatan antroposentris, sehingga dalam penyelenggarannya masih banyak dilakukan penyesuaian untuk mengadakan pendekatan pengelolaan sumber daya alam yang fokusnya lebih sempit dan terbatas (sektoral) sesuai dengan kebutuhan para pihak yang berkepentingan serta diwujudkan pengaturan hukumnya dalam bentuk undang-undang. Penyesuaian ini dapat mengakibatkan suatu kompromi yang berdasarkan penafsiran tidak lengkap terhadap kebutuhan sektor yang lebih luas maupun pertimbangan ekologisnya. Sehingga praktek pengelolaan dengan pendekatan antroposentris ini sangat menyulitkan manakala dihadapkan pada wilayah yang secara geografis terdiri dari ribuan pulau yang tergabung dalam lima kepulauan besar di Indonesia yakni: Pulau Sumatera, Pulau Jawa, Pulau Kalimantan, Pulau Sulawesi dan Pulau Irian. Kondisi geografis yang bersifat kepulauan ini dengan keanekaragaman ekologisnya berimplikasikan pada suatu kenyataan bahwa setiap daerah dalam pengelolaan dan pengalokasian sumber daya air untuk tergantung terhadap daerah lainnya.

Krisis air yang dialami oleh banyak wilayah di Indonesia berakar dari penggunaan paradigma yang berbasiskan negara (state-based water resource control and management). Paradigma negara seperti tertuang dalam konstitusi maupun perundang-undangan yang merupakan cerminan dari artikulasi nilai dan norma serta konfigurasi hukum negara yang mengatur penguasaan dan pengelolaan sumber daya air. 
Ekspresi dari ideologi yang memberi otoritas dan legitimasi kepada negara untuk menguasai dan mengelola sumber daya air, yaitu mengklaim, menguasai, mengatur, mengelola dan mengusahakan sesuai dengan kepentingan negara. Praktek pengelolaan dalam pemanfaatan air dan sumber-sumbernya yang berbasis negara (state-based water resource control and management) ini juga sangat menyulitkan manakala dihadapkan pada wilayah yang secara geografis terdiri dari ribuan pulau dengan kondisi ekologis yang berbeda-beda.

Sehubungan dengan penggunaan paradigma negara dalam pengelolaan sumber daya alam, menurut I Nyoman Nurjaya dengan mengutip pendapat Korten (1986) bahwa institusi penguasa dan pengelola sumber daya yang berbasiskan negara cenderung mengelola sumber daya alam secara sentralistik (centralized resources allocation) dan pola penyusunan dan penyampaian program yang bersifat standar (standardized service delivery programs), untuk keseragaman dan efisiensi di pihak pengambil keputusan. ${ }^{23}$ Dalam perkembangan dekade terakhir masyarakat selalu mempertanyakan terhadap aturan-aturan serta pelaksanaan yang berkaitan dengan pengelolaan dan alokasi sumber daya air yang berbasis negara (state-based water resource control and management) yang cenderung mengelola sumber daya air secara sentralistik (centralized resources allocation).

Kondisi ketersediaan air dan pengalokasiannya yang semakin berkurang akan bertambah lebih buruk dengan perkembangan ekonomi dan pertambahan penduduk yang demikian cepat, konflik-konflik yang terjadi dalam masyarakat yang belum terselesaikan, tidak adanya koordinasi pembangunan regional, ekonomi, dan lingkungan sehingga menghadapkan pemerintah untuk menggunakan paradigma baru dalam pengelolaan dan pemanfaatan air dan sumber-sumbernya. Perubahan paradigma pengelolaan sumber daya air sangat mendesak dari paradigma sentralistik ke paradigma desentralistik dengan semangat pemberdayaan (kemandirian). ${ }^{24}$

Sebagai reaksi dan koreksi atas penggunaan paradigma pengelolaan dalam pemanfaatan air dan sumber-sumbernya yang berbasiskan negara (state-based water resource control and management) tersebut, maka sejak dekade terakhir menurut I Nyoman Nurjaya telah diperkenalkan paradigma baru yang berorientasi pada kesejahteraan masyarakat lokal (community-based water resources management). ${ }^{25}$ Gagasan untuk mengedepankan paradigma ini bermula dari desakan kalangan organisasi non-pemerintah agar melibatkan dan memasukkan 
dimensi masyarakat lokal dalam pengelolaan sumber daya air. Pengelolaan atas sumber daya air dengan menggunakan paradigma negara ternyata memarjinalkan partisipasi masyarakat lokal dan terbukti tidak memberikan hasil yang optimal. Dengan demikian sangat mendesak untuk segera menggunakan paradigma baru dalam kehidupan bermasyarakat, berbangsa dan bernegara, yaitu paradigma masyarakat dengan semangat penguatan civil society.

Sejarah pengelolaan sumber daya air telah menunjukkan bahwa masyarakat lokal telah memiliki kearifan ekologi dan mampu menyelenggarakan pengelolaan dalam pemanfaatan sumber daya air secara berkelanjutan. Dengan demikian pengelolaan sumber daya alam, termasuk air serta sumber-sumbernya adalah berdimensi manusia dan ekologis sebagai bagian dari ekosistem yang seharusnya dipertimbangkan sebagai kesatuan. Perkembangan pengelolaan sumber daya air yang berbasiskan kerakyatan melalui kelembagaan formal dan peranannya belum menjamin terpenuhinya kebutuhan masyarakat, bahkan sering mengakibatkan penundaan terhadap masalah serius untuk kebutuhan masa depan bangsa, karena kendala birokrasi pemerintah yang belum melaksanakan reformasi organisasi publik (termasuk pemerintahan daerah). Hal demikian ini lebih disebabkan untuk memenuhi peraturan belaka daripada harapan birokrasi pemerintah untuk mereformasi diri dalam mewujudkan pendekatan baru dalam pengelolaan sumber daya air yang berorientasi pada kesejahteraan masyarakat lokal (communitybased water resources management).

\section{Kesimpulan}

Praktek pengelolaan sumber daya air di dalam negara yang baru merdeka selama ini telah diketemukan adanya kecenderungan pengelolaan tersebut dilaksanakan hanya berdasarkan pada salah satu aspek utama yaitu untuk memenuhi pertumbuhan ekonomi, sehingga aspek yang lain belum terpenuhi yaitu pemerataan hasil pembangunan untuk sebesar-besarnya kemakmuran rakyat. Hal ini mengakibatkan kegagalan dalam pelaksanaan pembangunan sumber daya air nasional yang dapat ditunjukkan dengan adanya ketidakberhasilan Pemerintah dalam menangani problema banjir dan kekeringan yang muncul setiap tahunnya. Kegagalan Pemerintah ini terkait dengan penggunaan paradigma hukum yang sentralistik dengan pendekatan kekuasaan dalam memenuhi pertumbuhan ekonomi 
nasional. Sejogyanya didalam pelaksanaan pembangunan sumber daya air nasional yang sangat mendesak yakni perubahan paradigma hukum yang sentralistik dengan pendekatan konsep antroposentrik menjadi paradigma hukum desentralistik dengan pendekatan konsep holism. Dengan demikian pengelolaan sumber daya air nasional yang berorientasi pada kesejahteraan masyarakat (community based water resources management ) dapat memberikan hasil/tujuan secara optimal untuk sebesar-besarnya kemakmuran rakyat sebagaimana yang telah diamanatkan dalam konstitusi Negara Republik Indonesia.

\section{Endnotes:}

1 "... dan apa yang Allah turunkan dari langit berupa aỉr, lalu dengan air itu Dia hidupkan bumi sesudah mati (kering)nya ...."

2 "... dan kamu lihat bumi ini kering, kemudian apabila telah Kami turunkan air atasnya. hiduplah bumi itu dan suburlah dan menumbuhkan berbagai macam tumbuh-tumbuhan yang indah."

3 "Dialah yang meniupkan angin (sebagai) pembawa kabar gembira dekat sebelum kedatangan rahmat-Nya (hujan); dan kami turunkan dari langit air yang amat bersih."

- "Dan kami turunkan dari langit air yang amat banyak manfaatnya lalu Kami tumbuhkan dengan air itu pohon-pohon ...."

5 Mengenai kalkulasi angka tentang istilah air tersebut diambil dari tulisan Djoko Pitono tentang : Krisis Air, Perang, dan Ketamakan Manusia, Jawa Pos, Juni 2003. Penyebutan hal tersebut belum rermasuk frasa 'air mancur', 'mata air', 'hujan es', kata 'awan' dan 'angin'.

6 Soenarno, Institutional aspects of sustainable water resources development. Dalam Water Resources for Sustainable Use in Indonesia, Proceeding of the International Seminar. Sponsored by National Planning Agency and Ministry of Public Works, Bogor, October 29 - November 1, 1992, halaman 3. Dalam perkembangan terakhir, Nugroho Sulistyo Priyono, Kepala Badan Penelitian Teknologi Daerah Aliran Sungai di Solo, menyatakan bahwa pihak yang paling merasakan musim kemarau adalah para petani, karena sekitar $87 \%$ pengguna air adalah bidang pertanian. Selebihnya digunakan dalam sektor domestik dan perindustrian. Dalam Kompas, Bila Sistem Hidrologi Terganggu, 15 Agustus 2003.

7 Lembaran Negara Republik Indonesia Tahun 1960 Nomor 104, Tambahan Lembaran Negara Republik Indonesia Nomor 2043.

* A.P. Parlindungan, Apakah UUPA Perlu Direformasi, Prisma No. 9, September, 1996. halaman 3.

9 I Nyoman Nurjaya, Menuju pengelolaan sumber daya hutan yang berorientasi pada pola kooperatif: perspektif legal formal, dalam Workshop, "Peningkatan Fungsi 
dan Manfaat Sumber Daya Hutan untuk Pengembangan Perusahaan dan Kesejahteraan Masyarakat", Yogyakarta, 29-30 Maret 1999, halaman 7.(Selanjutnya disebut I Nyoman Nurjaya I)

10 Philip Nonet \& Philippe Selznick, Law and Sociery in Transition, Toward Responsive Law, Harpher Colophon Books, New York, 1978, halaman: 14-15. Nonet \& Selznick (1978 : 53-54: 73-76) menawarkan tiga konsep tipe hukum, yaitu: repressive law, autonomous law dan responsive law yang menggambarkan tiga tahap perkembangan hukum sebagai akibat perkembangan sosial, politik dan ekonomi :'...repressive, autonomous, and responsive law are not only distinct of law, but, in some sense. stages of evolution in the relation of law to the political and social order'.

"I Nyoman Nurjaya, Proses pemiskinan di sektor hutan dan sumber daya alam: perspektif politik hukum, mimeo, makalah pada Seminar dan Workshop, Strategi Pemberdayaan Ekonomi Sistem Hutan Kerakyatan: Sebuah Agenda Penanggulangan Kemiskian Struktural, diselenggarakan oleh KpSHK \& KIKIS di Puncak-Jawa Barat, 08-20 Januari 2000. (Selanjutnya disebut I Nyoman Nurjaya II)

12 Berita pada Harian Kompas pada tanggal 10 Agustus 1998, "Nasib Korban Pencemaran Lampung."

13 L.M. Friedman, Legal culture and welfare state. Dalam Gunther Teubner : Dilemmas of Law in The Welfare State. Walter de Gruyter, Firenze, 1986, halaman 13. Pemahaman inj dapat dijelaskan lebih lanjut bahwa dalam sebuah negara yang melakukan intervensi terhadap kehidupan sosial masyarakat tampaknya akan membatasi ruang gerak masyarakat. Tujuan utama negara yang berupaya untuk mencapai kesejahteraan rakyat dapat dikesampingkan dengan tujuan lain yang lebih menguntungkan bagi negara.

14 Istilah 'paradigma negara' dikemukakan oleh A. Mukthie Fadjar dalam rulisannya: Menyoal kembali perubahan UUD 1945. Dalam A.Mukthie Fadjar, Kapito Selekta Politik Hukum, PPSUB, Malang, 2000.

${ }^{15}$ L.M. Friedman, Legal culture and welfare state. Dalam Gunther Teubner : Dilemmas of Law' in The Welfare State., Op.Cit., halaman 15.

${ }^{16}$ Boedi Harsono, Hukum Agraria Indonesia: Himpunan Peraturan-Peraturan Hukum Tanah, Penerbit Djambatan, 1983. Jakarta, halaman 5-6.

17 A. Mukthie Fadjar, Op.Cit.

I* Moeljarto, Politik Pembangunan, Sebuah Analisis, Konsep, Arah dan Srrategi. Tiara Wacana, Yogyakarta, 1993, halaman 11 dan 17. Moeljarto menyatakan konsep pertumbuhan ekonomi didasarkan pada asumsi bahwa tingginya tingkat pertumbuhan akan menciptakan pemerataan pendapatan. Artinya, pembangunan ekonomi harus terlebih dahulu mencapai tingkat pertumbuhan ekonomi yang tinggi, baru kemudian pemerataan ekonomi akan dapat dilaksanakan. Pemerataan ekonomi yang diharapkan didalam konsep tersebut ternyata tidak sampai pada tujuan. Lebih jauh Moeljarto menegaskan bahwa antiklimaks didalam pertumbuhan ekonomi yang terjadi setelah tahun 1980/1981 membawa kepada pemikiran tentang validitas atau kelaikan paradigma pertumbuhan yang selama ini menjadi acuan pembangunan nasional.

${ }^{19}$ A.Mukthie Fadjar, Op.Cit.

Ulul Albab, Vol. 5 No. 1, 2004 
20 Hubungan simbiosis nutualisma antara elit kekuasaan yang bersifat sentralistik dengan kalangan pengusaha mengandung ciri dengan apa yang disebut "governance as a private enterprise". Ciri tersebut nampaknya juga telah mewarnai dalam draft Rancangan Undang-Undang Sumber Daya Air. Dalam hal ini tujuan pemerintah dan usaha swasta berbaur dan menjadi tidak jelas, sehingga kepentingan dan hak-hak rakyat atas pengelolaan dan alokasi air beserta sumber-sumbernya yang sejak dulu dilakukan pada akhirnya banyak yang tersingkirkan.

${ }^{21}$ Harald D. Frederiksen, Institutional Principles for Sound Management of Water and Related Environmental Resources, dalam Asit K. Biswas, Water Resources: Environmental Planning, Management, and Development, McGraw-Hill, New York, 1996, halaman 534.

$\because$ Lembaran Negara Republik Indonesia Tahun 1997, Nomor 68, Tambahan Lembaran Negara Nomor 3699.

2.. I Nyoman Nurjaya I, Op.Cit, halaman 5

${ }^{24}$ A. Mukthie Fadjar, Op.Cit.

${ }^{25}$ I Nyoman Nurjaya, Op. Cit.

\section{Bibliografi}

Biswas, Asit. K.,1996, Water development and environment, dalam Water Resources: Environmental Planning, Management, and Development (edited Asit K. Biswas), Mc Graw Hill, New York.

Fadjar, A.Mukthie, 2000, Menyoal kembali perubahan UUD 1945, dalam Kapita Selekta Politik Hukum (Penyunting: A. Mukthie Fadjar), Program Pasca Sarjana Universitas Brawijaya, Malang.

Frederiksen, Harald D.,1996, Institutional principles for sound management of water and related environmental resources, dalam Water Resources: Environmental Planning, Management, and Development (edited Asit K. Biswas), McGraw-Hill, New York.

Friedman, L.M., 1986, Legal culture and welfare state, dalam Dilemmas of Law in the welfare state (edited Gunther Teubner), Walter de Gruyter, Firenze.

Nonet, Philip \& Philippe Selznick, 1978, Law and Society in Transition, Toward Responsive law, Harpher Colophon Books, New York.

Nurjaya, I Nyoman, Menuju pengelolaan sumber daya hutan yang berorientasi pada pola kooperatif:perspektif legal formal. dalam Workshop, "Peningkatan Fungsi dan Manfaat Sumber Daya Hutan untuk 
Pengembangan Perusahaan dan Kesejahteraan Masyarakat", Yogyakarta, 29-30 Maret 1999.

......, Proses pemiskinan di sektor hutan dan sumber daya alam: perspektif politik hukum. Mimeo, Makalah pada seminar dan Workshop Strategi Pemberdayaan Ekonomi Sistem Hutan Kerakyatan, sebuah Agenda Penanggulangan Kemiskinan Struktural. diselenggarakan oleh KpSHK \& KIKIS di Puncak, Jawa Barat, 08-20 Januari 2000.

Parlindungan, AP., 1996, Apakah UUPA Perlu Direformasi, Prisma No. 9 , September.

Soenamo, Institutional aspects of sustainable water resources development, dalam Integrated Development and Management of Water Resources for Sustainable Use in Indonesia, Proceedings of the International Seminar October 29 - November 1, 1992. 